\title{
Chemical composition and seasonal variation of the volatile oils from leaves of Michelia champaca L., Magnoliaceae
}

\author{
João Henrique G. Lago, ${ }^{, 1}$ Oriana A. Fávero, ${ }^{2}$ Paulete Romoff ${ }^{2}$
}

${ }^{1}$ Departamento de Ciências Exatas e da Terra, Universidade Federal de São Paulo, 09972-270 Diadema-SP, Brazil

${ }^{2}$ Centro de Ciências e Humanidades e Centro de Ciências Biológicas e da Saúde, Universidade

Presbiteriana Mackenzie, 01302-907 São Paulo-SP, Brazil.

\begin{abstract}
RESUMO: “Composição química e variação sazonal dos óleos voláteis das folhas de Michelia champaca L., Magnoliaceae". Os óleos voláteis das folhas de Michelia champaca L., coletadas bimestralmente ao longo de um ano (quatro vezes no décimo quinto dia de janeiro, março, maio, julho, setembro e novembro de 2004), foram submetidos à análise por CG/DIC e CG-EM, de onde foram identificados treze componentes. Adicionalmente, parte do óleo obtido na coleta de janeiro foi submetida a fracionamento em gel de sílica impregnada com $\mathrm{AgNO}_{3}$ fornecendo cinco dos principais sesquiterpenos ( $\beta$-elemeno, $\beta$-cariofileno, $\alpha$-humuleno, $\beta$-selineno e $\alpha$-cadinol). Os dados obtidos mostram uma variação significativa na proporção dos componentes, a qual pode estar associada a parâmetros microclimáticos em cada período de coleta.
\end{abstract}

Unitermos: Michelia champaca, terpenoides, variação sazonal.

\begin{abstract}
The volatile oils from leaves of Michelia champaca L. collected bimonthly during one year (four times on the fifteenth day of January, March, May, July, September, and November - 2004) were subjected to GC/FID and GC-MS analysis, from which thirteen components were identified. Additionally, part of the oil obtained from January collection was subjected to fractionation over silica gel soaked with $\mathrm{AgNO}_{3}$ to afford five of the main sesquiterpenes ( $\beta$-elemene, $\beta$-caryophyllene, $\alpha$-humulene, $\beta$-selinene, and $\alpha$-cadinol). The obtained data showed a significative variation in the proportions of the components, which could be associated to climatic parameters in each collection periods.
\end{abstract}

Keywords: Michelia champaca, terpenoids, seasonal variation.

\section{INTRODUCTION}

Michelia champaca L., Magnoliaceae, is a tree native in Taiwan, Malasya and China which is also cultivated in Brazil (Corrêa, 1984). This specie has been used in folk medicine to the treatment for rheumatism (Sharma \& Mehta, 1998; Monteiro et al., 2007). Several phytochemical studies reported the occurrence of sesquiterpene lactones, alkaloids, flavonoids, tannins, and saponins in leaves, stems and roots of M. champaca (Monteiro et al., 2007; Jacobsson et al., 1995; Khan et al., 2002). The volatile oil from leaves of $M$. champaca was composed by several compounds, mainly benzyl acetate, linalool, isoeugenol and has been used as a starting material for perfums (Lai \& Lee, 1994).

However, there is no information in the literature about the dynamics in the proportions of the components of the oil from leaves of Brazilian M. champaca, Magnoliaceae. Thus, in this report we describe the identification and the variation of the chemical constituents in these oils obtained bimonthly during one year (four collections at fifteenth day at January, March, May, July, September, and November 2004).

\section{MATERIAL AND METHODS}

\section{Plant material}

Leaves were collected bimonthly (fifteenth day, in four times during a day ( $8 \mathrm{am}, 12 \mathrm{am}, 4 \mathrm{pm}, 8 \mathrm{pm})$, from January/2004 to November/2004 from a specimen which is growing in the center of São Paulo city (Mackenzie University Campus). Identification of the plant material was performed by Dr. Lucia Rossi. Voucher specimen was deposited in the Herbarium of Instituto Florestal, São Paulo-SP, Brazil.

\section{Volatile oil isolation}

Leaves of each collection (approximately $200 \mathrm{~g}$ ) were subjected to hydrodistillation for four hours using a Clevenger-type apparatus. The oils were 
separated from water using $\mathrm{CH}_{2} \mathrm{Cl}_{2}$ as solvent, dried over anhydrous $\mathrm{Na}_{2} \mathrm{SO}_{4}$ and stored at $4{ }^{\circ} \mathrm{C}$ in the dark. After solvent evaporation, the oil from Michelia champaca L. (Magnoliaceae) was submitted to analysis by GC/FID and GC-MS (Lago et al., 2003). The yield of crude volatile oils from $M$. champaca was approximately constant $(0.04 \%)$ in all different seasons.

\section{Volatile oil fractionation}

Part of the crude oil from collection of January 2004 (approximately $150 \mathrm{mg}$ ) was submitted to column chromatography over silica gel soaked with $\mathrm{AgNO}_{3}(15 \%)$ (50 g, $55 \times 2 \mathrm{~cm})$ eluted with pentane $(100 \mathrm{~mL}), \mathrm{CH} 2 \mathrm{Cl} 2$ $(150 \mathrm{~mL})$ and mixtures of $\mathrm{CH}_{2} \mathrm{Cl}_{2}: \mathrm{Me}_{2} \mathrm{CO} 9: 1(100 \mathrm{~mL})$ and $8: 2(50 \mathrm{~mL})$, to afford fifty four fractions, which were analyzed by GC/FID and pooled together in eleven groups (A-1 to A-11) (Brochini et al., 1999; Brochini \& Lago, 2007). This analysis indicated that some groups were composed by one major derivative and had their NMR spectra recorded. Therefore, the compounds $\beta$-elemene (group A-3), $\beta$-caryophyllene (group A-4), $\alpha$-humulene (group A-6), $\beta$-selinene (group A-7) and $\alpha$-cadinol (group A-9) were identified after comparison of those reported in the literature (Adio et al., 2004; Kanokmedhakul et al., 2007; Rivero-Cruz et al., 2006; Momin et al., 2000).

\section{GC}

A Hewlet-Packard 5890 series II equipped with FID detector and a capillary column HP-5, crosslinked 5\% phenyl in methyl silicone (30 m x $0.32 \mathrm{~mm}$; film thickness $0.25 \mu \mathrm{m}$ ), an automatic injector (HP 7673) and electronic integrator (HP 3396A) were used. The temperature programming was performed from $50{ }^{\circ} \mathrm{C}$, isothermal from $2 \mathrm{~min}, 50^{\circ}-280{ }^{\circ} \mathrm{C}$ at $5{ }^{\circ} \mathrm{C} / \mathrm{min}$, then isothermal at $280{ }^{\circ} \mathrm{C}$ for $5 \mathrm{~min}$. The injector and detector temperatures were 180 ${ }^{\circ} \mathrm{C}$ and $260{ }^{\circ} \mathrm{C}$, respectively. Helium was used as the carrier gas $\left(1 \mathrm{~mL} \cdot \mathrm{min}^{-1}\right)$ and the split range was 1:50. Quantitative data were obtained from electronic integration of the area percent data without the use of internal standard or correction factors.

\section{GC-MS}

The GC-MS analysis were carried out in as EIMS $70 \mathrm{eV}$ Hewlet-Packard HP-5973 (mass range from 40 to 350) coupled with a Hewlet-Packard HP-6890 with DB-5 column (30 m x $0.25 \mathrm{~mm}$, film thickness $0.25 \mu \mathrm{m})$ using the same temperature programming conditions described above. The identification of the compounds was performed by comparing the mass spectra with those of authentic samples (Adams, 2001) and the retention indices, which were determined relatively to the retention time of a series of $n$-alkanes.

\section{NMR}

NMR spectra were recorded on a Bruker DPX300 spectrometer operating at $75 \mathrm{MHz}$ to ${ }^{13} \mathrm{C}$ and $300 \mathrm{MHz}$ to ${ }^{1} \mathrm{H}$, using $\mathrm{CDCl}_{3}$ (Tedia Brazil) as solvent and TMS as internal standard.

\section{RESULTS AND DISCUSSION}

The present article describes the chemical composition and variation on the relative amounts of constituents of the volatile oils from leaves of Michelia champaca L. (Magnoliaceae), which was carried out on six bimonthly collections over the period from January to November 2004 (four collections at fifteenth day). The essential oils were obtained by steam distillation and analyzed by GC-FID and GC-MS. The medium values of the relative amount of each compound identified in the crude oils are presented in Table I. Additionally, part of the oil obtained from leaves of January collection was subjected to fractionation over silica gel soaked with $\mathrm{AgNO}_{3}$ $(15 \%)$. Analysis of the fractions composed by one major derivative using GC-FID, ${ }^{1} \mathrm{H}$ and ${ }^{13} \mathrm{C}$ NMR spectroscopy allowed the identification of the sesquiterpenes $\beta$-elemene, $\beta$-caryophyllene, $\alpha$-humulene, $\beta$-selinene, and $\alpha$-cadinol.

In a qualitative point of view, the oils contained thirteen identified compounds, corresponding to one monoterpene ( $\alpha$-terpinolene), six sesquiterpene hydrocarbons ( $\beta$-elemene, $\beta$-caryophyllene, $\alpha$-humulene, $\beta$-selinene, $\alpha$-selinene, and $\gamma$-cadinene), four oxygenated sesquiterpenes $[(E)$-nerolidol, $\alpha$-cadinol, $\beta$-bisabolol, and $(Z, E)$-farnesol], and two aliphatic alcohols (pentadecanol and hexadecanol).

Quantitatively, the relative amount of hydrocarbon sesquiterpenes ( $\beta$-elemene, $\beta$-caryophyllene, and $\alpha$-humulene the main derivatives) was higher that the content of oxygenated derivatives during all collections $(47-69 \%)$. Otherwise, the amount of oxygenated sesquiterpenes showed to be constant (5-7\%) during January, March, May, July and December, increasing up to $21 \%$ in September. Despite of the occurrence of terpenoid derivatives as main derivatives, aliphatic $\mathrm{C}_{15}$ and $\mathrm{C}_{16}$ alcohols were also detected in all collection, being their relative amount constant during all year (14-17\%).

Finally, it is important mentioned that the variations in the chemicals of the oils could be associated to microclimatic parameters such as precipitation, temperature or phenological state, which showed to be different in the collections of leaves from M. champaca and are known to affect the oil chemical compositions (Vallat et al., 2005; Lago et al., 2006). 
Table 1. Relative percentage composition of the leaf oils of Michelia champaca (January/2004-November/2004).

\begin{tabular}{|c|c|c|c|c|c|c|c|}
\hline Compounds & IK & January & March & May & July & September & November \\
\hline$\alpha$-terpinolene & 1088 & $2.1 \pm 0.2$ & $1.9 \pm 0.1$ & $2.4 \pm 0.3$ & $2.7 \pm 0.2$ & $2.5 \pm 0.3$ & $1.8 \pm 0.2$ \\
\hline$\beta$-elemene* & 1391 & $13.0 \pm 2.0$ & $12.0 \pm 3.0$ & $16.0 \pm 1.0$ & $8.8 \pm 0.9$ & $7.0 \pm 2.0$ & $15.0 \pm 2.0$ \\
\hline$\beta$-caryophyllene* & 1418 & $21.0 \pm 4.0$ & $23.0 \pm 3.0$ & $19.6 \pm 0.9$ & $25.0 \pm 5.0$ & $16.0 \pm 4.0$ & $24.0 \pm 3.0$ \\
\hline$\alpha$-humulene* & 1454 & $11.1 \pm 0.9$ & $10.0 \pm 2.0$ & $13.6 \pm 0.6$ & $10.0 \pm 2.0$ & $9.4 \pm 0.9$ & $14.0 \pm 1.0$ \\
\hline$\beta$-selinene* & 1485 & $8.0 \pm 1.0$ & $8.2 \pm 0.7$ & $7.8 \pm 0.4$ & $8.1 \pm 0.6$ & $8.2 \pm 0.7$ & $9.2 \pm 0.9$ \\
\hline$\alpha$-selinene & 1494 & $6.9 \pm 0.6$ & $5.2 \pm 0.5$ & $6.2 \pm 0.4$ & $5.9 \pm 0.7$ & $5.3 \pm 0.8$ & $5.3 \pm 0.5$ \\
\hline$\gamma$-cadinene & 1513 & $1.42 \pm 0.07$ & $0.95 \pm 0.07$ & $1.2 \pm 0.1$ & $1.6 \pm 0.2$ & $1.31 \pm 0.08$ & $1.56 \pm 0.06$ \\
\hline$(E)$-nerolidol & 1564 & $1.5 \pm 0.2$ & - & - & $2.6 \pm 0.4$ & $9.5 \pm 0.9$ & $3.7 \pm 0.7$ \\
\hline$\alpha$-cadinol* & 1653 & $1.3 \pm 0.7$ & $2.5 \pm 0.5$ & - & - & $7.3 \pm 0.7$ & - \\
\hline$\beta$-bisabolol & 1671 & $3.2 \pm 0.4$ & $2.9 \pm 0.6$ & $3.7 \pm 0.4$ & $3.3 \pm 0.5$ & $2.7 \pm 0.4$ & $3.0 \pm 0.6$ \\
\hline$(Z, E)$-farnesol & 1697 & $1.06 \pm 0.01$ & - & $0.98 \pm 0.02$ & - & $1.29 \pm 0.07$ & - \\
\hline pentadecanol & 1778 & $7.2 \pm 0.9$ & $7.5 \pm 0.8$ & $8.9 \pm 0.8$ & $8.0 \pm 2.0$ & $9.0 \pm 2.0$ & $7.2 \pm 0.8$ \\
\hline hexadecanol & 1879 & $6.4 \pm 0.3$ & $7.1 \pm 0.7$ & $8.0 \pm 3.0$ & $5.8 \pm 0.9$ & $8.2 \pm 0.7$ & $6.9 \pm 0.7$ \\
\hline \multicolumn{2}{|l|}{ Monoterpenes } & $2.1 \pm 0.2$ & $1.9 \pm 0.1$ & $2.4 \pm 0.3$ & $2.7 \pm 0.2$ & $2.5 \pm 0.3$ & $1.8 \pm 0.2$ \\
\hline \multicolumn{2}{|c|}{ Sesquiterpene hydrocarbons } & $61.0 \pm 4.0$ & $59.0 \pm 3.0$ & $64.0 \pm 1.0$ & $59.0 \pm 5.0$ & $47.0 \pm 4.0$ & $69.0 \pm 3.0$ \\
\hline \multicolumn{2}{|c|}{ Oxygenated sesquiterpenes } & $7.0 \pm 0.7$ & $5.4 \pm 0.6$ & $4.7 \pm 0.4$ & $5.9 \pm 0.5$ & $20.8 \pm 0.9$ & $6.7 \pm 0.7$ \\
\hline \multicolumn{2}{|l|}{ Other metabolites } & $13.6 \pm 0.9$ & $14.6 \pm 0.8$ & $17.0 \pm 3.0$ & $14.0 \pm 2.0$ & $17.0 \pm 2.0$ & $14.1 \pm 0.8$ \\
\hline & TOTAL & $84.0 \pm 4.0$ & $81.0 \pm 3.0$ & $88.0 \pm 3.0$ & $82.0 \pm 5.0$ & $87.0 \pm 4.0$ & $92.0 \pm 3.0$ \\
\hline
\end{tabular}

*also identified by NMR after chromatographic separation.

\section{ACKNOWLEDGEMENTS}

The authors are grateful to MackPesquisa and FAPESP for the financial support and scholarships.

\section{REFERENCES}

Adams RP 2001. Identification of essential oil components by gas chromatography/quadrupole mass spectrometry. Illinois: Allured Publishing Corporation.

Adio AM, Paul C, Kloth P, König WA 2004. Sesquiterpenes of a liverwort Scapania undulate. Phytochemistry 65: 199206.

Brochini CB, Lago JHG 2007. Aplicação de técnicas cromatográficas e espectrométricas como ferramentas de auxílio na identificação de componentes de óleos voláteis. Rev Bras Farmacogn 17: 266-270.

Brochini CB, Nunez CV, Moreira IC, Roque NF, Chaves MH, Martins D 1999. Identificação de componentes de óleos voláteis: análise espectroscópica de misturas de sesquiterpenos. Quim Nova 22: 37-40.

Corrêa MP 1984. Dicionário de plantas úteis do Brasil e das exóticas cultivadas. Rio de Janeiro: Imprensa Nacional.

Jacobsson U, Kumar V, Saminathan S 1995. Sesquiterpene lactones from Michelia champaca. Phytochemistry 39: 839-843.

Kanokmedhakul S, Kanokmedhakul K, Lekphrom R 2007. Bioactive constituents of the roots of Polyalthia cerasoides. J Nat Prod 70: 1536-1538.

Khan MR, Kihara M, Omoloso AD 2002. Antimicrobial activity of Michelia champaca. Fitoterapia 73: 744-748.
Lago JHG, Ávila Jr. P, Moreno PRH, Limberger RP, Apel MA, Henriques AT 2003. Analysis, comparison and variation in the chemical composition from the leaf volatile oil of Xylopia aromatica (Annonaceae). Biochem Syst Ecol 31: 669-672.

Lago JHG, Fávero OA, Romoff P 2006. Microclimatic factors and phenology influences on the chemical compositions of the essential oils from Pittosporum undulatum Vent. leaves. J Braz Chem Soc 17: 1334-1338.

Lai Y-C, Lee W-C 1994. The initiation of callus culture of Michelia champaca for essential oil production. Biotechnol Lett 16: 85-88.

Momin RA, Ramsewak RS, Nair MG 2000. Bioactive compounds and 1,3-Di[(cis)-9-octadecenoyl]-2-[(cis,cis)-9,12octadecadienoyl]glycerol from Apium graveolens L. seeds. J Agric Food Chem 48: 3785-3788.

Monteiro MCM, Leptokarydis IH, Silva GH, Silva VC, Bolzani VS, Young MCM, Lopes MN 2007. Constituintes químicos isolados dos caules de Michelia champaca L. (Magnoliaceae). Eclet Quim 32: 13-18.

Rivero-Cruz B, Rivero-Cruz I, Rodriguez JM, Cerda-GaricaRojas CM, Mata R 2006. Qualitative and quantitative analysis of the active components of the essential oil from Brickellia veronicaefolia by nuclear magnetic resonance spectroscopy. J Nat Prod 69: 1172-1176.

Sharma S, Mehta SH 1998. Isolation and characterization of a novel amide from Michelia champaca. Indian J Chem 37B: 1219-1220.

Vallat A, Gu H, Dorn S 2005. How rainfall, relative humidity and temperature influence volatile emissions from apple trees in situ. Phytochemistry 66: 1540-1550. 